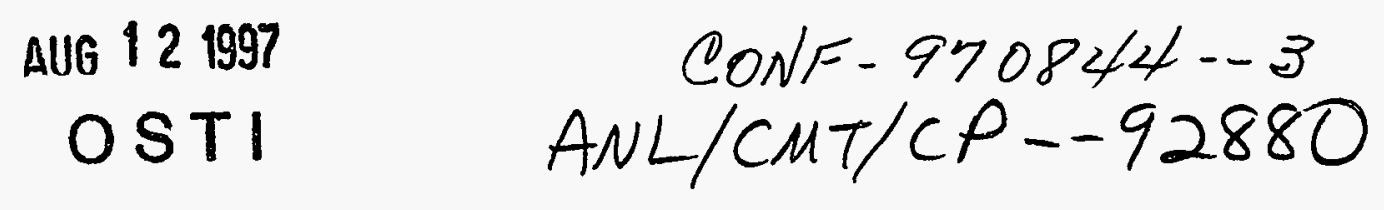

\title{
Plutonium Alteration Phases from Lanthanide Borosilicate Glass
}

\author{
J. A. Fortner, C. J. Mertz, D. C. Chamberlain, and J. K. Bates
}

\author{
Argonne National Laboratory \\ Chemical Technology Division \\ 9700 South Cass Avenue \\ Argonne, IL 60439
}

Submitted to the Meeting

Pu-Futures - The Science

Santa Fe, New Mexico

August 25-27, 1997

The submitted manuscript has been

authored by a contractor of the U.S.

Government under contract No. $W$ -

31-108-ENG-38. Accordingly, the

US Govemment retains

nonexclusive, royalty-free license

to publish or restly

put the

published form of this contribution,

or allow others to do so, for U.S.

Govemment purposes.

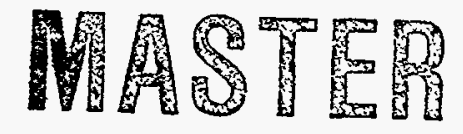

DISTREUTHON OF THS DOCUHENT S UMAMTEO

This work is supported by the U. S. Department of Energy, Office of Fissile Materials Disposition, under contract W-31-109-ENG-58. 


\section{DISCLAIMIER}

Portions of this document may be illegible in electronic image products. Images are produced from the best available original document. 


\section{DISCLAIMER}

This report was prepared as an account of work sponsored by an agency of the United States Government. Neither the United States Government nor any agency thereof, nor any of their employees, make any warranty, express or implied, or assumes any legal liability or responsibility for the accuracy, completeness, or usefulness of any information, apparatus, product, or process disclosed, or represents that its use would not infringe privately owned rights. Reference herein to any specific commercial product, process, or service by trade name, trademark, manufacturer, or otherwise does not necessarily constitute or imply its endorsement, recommendation, or favoring by the United States Government or any agency thereof. The views and opinions of authors expressed herein do not necessarily state or reflect those of the United States Government or any agency thereof. 


\title{
PLUTONIUM ALTERATION PHASES FROM LANTHANIDE BOROSILICATE GLASS
}

\author{
J. A. Fortner, C. J. Mertz, D. C. Chamberlain, and J. K. Bates
}

Argonne National Laboratory, Argonne, IL 60439

\section{ABSTRACT}

A prototype lanthanide borosilicate (LaBS) glass containing 10 mass \% plutonium was reacted with water vapor at $200^{\circ} \mathrm{C}$ for periods of 14 to 56 days. These tests, while not designed to replicate specific conditions that may be found in a potential geologic repository (e.g., Yucca Mountain), have been shown to accelerate alteration phase formation. ${ }^{1}$ The surfaces of the glass samples, along with alteration phases, were examined with a transmission electron microscope (TEM). Tests of 14 days produced macroscopic $(\sim 20 \mu \mathrm{m})$ crystallites of a plutonium-lanthanide silicate. An extensive alteration layer was found on the glass surface containing amorphous aluminosilicate layered with bands of a cryptocrystalline plutonium silicate. After 56 days of testing, additional alteration phases were formed, including a strontium lanthanide oxide phase.

One of the options for disposal of surplus plutonium, particularly for impure residues that may be unfit for production of MOX fuel, is vitrification followed by geologic disposal. ${ }^{2}$ Since geologic disposal requires a passive system to isolate the radiotoxic elements from the biosphere, it is important to understand the possible corrosion mechanisms of the waste form.

The LaBS glass, based upon Löffler-type glasses, is chemically durable and can dissolve substantial amounts of plutonium as well as the neutron absorbers gadolinium and hafnium. ${ }^{3,4}$ The prototype LaBS formulation tested in this work, however, contained no hafnium but did contain zirconium, which is expected to behave in a chemically similar manner. The Argonne Vapor Hydration Test procedure was used and is discussed in detail elsewhere. ${ }^{1}$ 
Two types of TEM samples were prepared: (1) surface alteration crystals, which were about $20 \mu \mathrm{m}$ across and affixed to the monolith surface, and (2) chips of glass, some of which held an intact surface alteration layer. The surface alteration crystals were found to be a plutonium lanthanide silicate. Electron energy loss spectroscopy revealed that the ratio of gadolinium to lanthanum in the alteration crystal was reduced more than a factor of two relative to the initial LaBS glass, although the gadolinium-to-plutonium ratio was nearly unchanged. The alteration surface layer, shown in Figure 1 for a 14-day test sample, contained bands of plutonium-rich silicates separated by amorphous aluminosilicates (probably hydroxides). The intralayer plutonium silicates were relatively depleted in lanthanide elements compared to surface crystals, although they produced similar electron diffraction patterns (Table 1). The compositional difference between the surface and intralayer crystals probably reflects solubility differences between the lanthanides and plutonium, the former being more readily transported to the surface of the glass as it alters.

Plutonium has not been previously reported as a major component in silicate alteration phases on glass. Nevertheless, the occurrence of plutonium in alteration phases has been expected because of its low release rate in tests of high-level waste glass ${ }^{6}$ and spent nuclear fuel..$^{7}$ Segregation was observed among the lanthanide elements lanthanum, neodymium, and gadolinium; also observed was separation of the lanthanides from plutonium. Corrosion tests (MCC-1 and PCT-B) of the LaBS glass ${ }^{8}$ indicate normalized release rates for lanthanides greater than for plutonium, with zirconium released at the lowest rate. Since gadolinium serves as a neutron absorber, its separation from the plutonium on a large scale may have implications for criticality. These combined data support the strategy of incorporating two neutron absorbers, gadolinium and hafnium, in the LaBS glass to provide for different corrosion scenarios. ${ }^{3}$ The occurrence of a strontium lanthanide phase, which contained no detectable plutonium, provided impetus for strontium to be omitted from more recent LaBS formulations. ${ }^{3}$ 


\section{ACKNOWLEDGMENTS}

Work supported by the U.S. Department of Energy, Office of Fissile Materials Disposition, under contract W-31-109-ENG-38.

\section{REFERENCES}

1. D. J. Wronkiewicz, et al., Mat. Res. Symp. Proc. Vol. 294 (1993) 183.

2. National Academy of Sciences, "Management and Disposition of Excess Weapons Plutonium: Reactor-Related Options," NAS Panel on Reactor-Related Options for the Disposition of Excess Weapons Plutonium (National Academy Press, Washington DC. 1995)

3. David K. Peeler, private communication.

4. N. E. Bibbler, et al., Mat. Res. Symp. Proc. Vol. 412 (1996) 65

5. JCPDS - International Centre for Diffraction Data PDF-2 Database JCPDS-ICDD International Centre for Diffraction Data (Newtown Square, PA. 1996).

6. J. A. Fortner and J. K. Bates, Mat. Res. Symp. Proc. Vol. 412 (1996) 205.

7. P. A. Finn, et al., Mat. Res. Symp. Proc. Vol. 412 (1996) 75.

8. C. J. Mertz and S. F. Wolf, unpublished results. 
Table 1. Electron diffraction spacings from the surface crystal and intralayer plutonium silicate crystallite compared with literature materials. Reference JCPDS-ICDD 5 data reported for $I I_{0} \geq 0.3$ or for match with experiment. The comparisons do not suggest an identification of the observed phases, but rather similar structural units.

\begin{tabular}{|c|c|c|c|c|}
\hline $\begin{array}{l}\text { Experimental } \\
\text { d-spacings, } \\
\text { surface } \\
\text { crystal } \\
\text { (nm) } \\
\end{array}$ & $\begin{array}{c}\text { Experimental } \\
\text { d-spacings, } \\
\text { intralayer } \\
\text { crystallite } \\
\text { (nm) }\end{array}$ & $\begin{array}{c}\mathrm{Nd}_{2} \mathrm{SiO}_{5} \\
\mathrm{JCPDS}-\mathrm{ICDD} \\
40-284 \\
(\mathrm{~nm})\end{array}$ & $\begin{array}{c}\mathrm{La}_{2} \mathrm{SiO}_{5} \\
\text { JCPDS-ICDD } \\
40-234 \\
(\mathrm{~nm})\end{array}$ & $\begin{array}{c}\mathrm{PuSiO}_{4} \\
\text { JCPDS-ICDD } \\
43-1095 \\
(\mathrm{~nm})\end{array}$ \\
\hline 0.489 & & $\begin{array}{l}0.4859 \\
0.4382\end{array}$ & 0.4418 & 0.4621 \\
\hline 0.387 & & 0.3891 & 0.3805 & \\
\hline 0.351 & $\begin{array}{l}0.338 \\
0.307 \\
0.310\end{array}$ & $\begin{array}{l}0.3413 \\
0.3180 \\
0.3128 \\
0.2937 \\
0.2853\end{array}$ & $\begin{array}{l}0.3511 \\
0.2945 \\
0.2992 \\
0.2850 \\
0.2831\end{array}$ & 0.3452 \\
\hline $\begin{array}{l}0.260 \\
0.245 \\
0.224\end{array}$ & 0.243 & $\begin{array}{l}0.2788 \\
0.2604 \\
0.2467 \\
0.2264 \\
0.2215\end{array}$ & $\begin{array}{l}0.2652 \\
0.2450 \\
0.2202 \\
0.2192\end{array}$ & $\begin{array}{l}0.2766 \\
0.2623 \\
0.24415 \\
0.21592\end{array}$ \\
\hline 0.202 & $\begin{array}{l}0.197 \\
0.195\end{array}$ & 0.20046 & $\begin{array}{l}0.2035 \\
0.1984\end{array}$ & 0.19860 \\
\hline $\begin{array}{l}0.187 \\
0.176\end{array}$ & $\begin{array}{l}0.192 \\
0.170\end{array}$ & $\begin{array}{l}0.18678 \\
0.17535\end{array}$ & $\begin{array}{l}0.1877 \\
0.17699\end{array}$ & $\begin{array}{l}0.18305 \\
0.17872 \\
017266\end{array}$ \\
\hline 0.1652 & 0.166 & 0.16580 & 0.16555 & 0.16174 \\
\hline
\end{tabular}




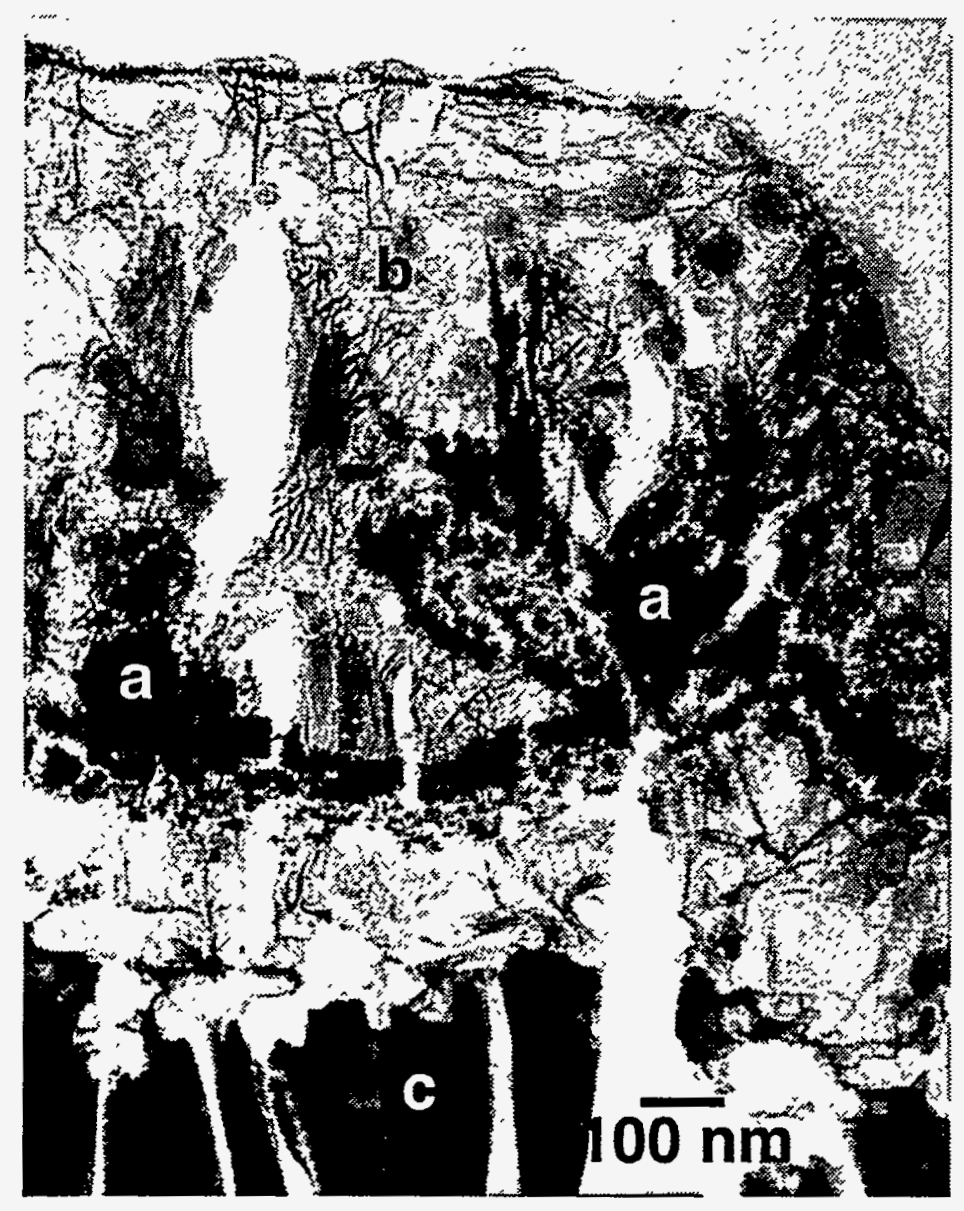

Figure 1. A TEM micrograph showing the alteration layer formed after a 14-day vapor hydration test. Visible are a) plutonium -silicate alteration crystals, b) amorphous aluminosilicate, and c) unaltered glass. 